\title{
The Relationship Between Depression and Violence Risk Predictors on Elderly
}

\author{
Joana Alegria Pereira ${ }^{1}$, Felismina Mendes ${ }^{1}$, Tatiana Mestre $^{1}$, Maria Otília Zangão ${ }^{1}$ \& Catarina Pereira ${ }^{1}$ \\ ${ }^{1}$ School of Nursing, Évora University, Portugal \\ Correspondence: Joana Alegria Pereira, School of Nursing, Évora University, Project ESACA: Ref.': \\ ALT20-03-0145-FEDER-000007, Portugal.
}

Received: November 17, 2018

Accepted: December 28, 2018

Online Published: January 8, 2019

doi:10.20849/ijsn.v4i1.536

URL: https://doi.org/10.20849/ijsn.v4i1.536

\begin{abstract}
The purpose of this study was to understand the correlation between the elderly with depressive symptomatology and the predictors of the risk of violence against them. The method used was a quantitative approach using the Statistical Package program for Social Sciences. There was a participation of 237 elderly people aged 65-96 years, of the project "Aging in Safety in Alentejo-Understanding to Act", at the University of Évora. The Geriatric Depression Scale and the Predictors of Risk of Violence (an adaptation of the Elder Abuse and Neglect-Risk Assessment Tool and Vulnerability to Abuse Screening Scale) were applied. About the results, 50 elderly $(21.1 \%)$ had mild depressive symptomatology, and 14 (5.9\%) had severe depressive symptomatology. Of the 64 elderly individuals who presented depressive symptomatology 55 were female. In the relationship between the severity of depressive symptomatology and predictors of risk of violence, significant results were found in three dimensions: current supports and relationships, family context and cognitive/emotional difficulties. The main conclusion of the study is that factors like no social support networks, complex family context and cognitive and emotional changes, contribute to greater physical and mental vulnerability of the elderly, resulting in cases of anxiety and stress, which present a depressive symptomatology and the risk of violence.
\end{abstract}

Keywords: elderly, violence, depression, risk predictors

\section{Introduction}

\subsection{Aging and Depression}

The average life expectancy has been increasing in recent decades. In Portugal, in the year 2016 it was 80.8 years, more specifically 84.4 years for women and 77.7 years for men (Pordata, 2018). In 2017, Portugal had a Longevity Index of 53, 2\% and an Aging Index of 148.7\%. The Alentejo region in 2016 had an aging index of 197, 0\%, much higher than the 153, 2\% which has prevailed in Portugal (Portada, 2018). In Portugal, from a statistical / legal point of view it is possible to define that it belongs to the social category of "elderly" from the age of 65. However, it is important to emphasize that this process does not develop uniformly, since behind each person there is a life and genetic history (Dias \& Ferreira, 2014).

According to Zimerman (2009), the social aging of the population changes the role of the elderly and their way of relate with others. These changes occur due to: an identity crisis, characterized by loss of self-esteem, caused by the absence of social role; changes in roles - adaptations to new roles resulting from the increase in their lifespan, and those changes occur at work, in the family and in society; loss of autonomy, independence, power of decision, and loss of relatives and friends; and the reduction of social contacts; and retirement / pension, in which elderly should be ready to not become isolated, depressed and often aimlessly. It is important to remember that both violence and depression are common problems in the elderly.

Currently, depression is regarded as a one of the major's public health problems, which affects about 121 million people worldwide. According to the World Health Organization (2008), this represents the fourth leading cause of global diseases in 2000, with projected to become the second in 2020.

In 2004, estimates all over the world as part of the World Health Organization concluded that 151.2 million people suffer from depressive disorders (Queiroz et al., 2009). With regard to Europe, mental illnesses are growing and it is estimated that these diseases have an effect on approximately 50 million people, ie $11 \%$ of the European population (Queiroz et al., 2009). 
During the aging process, depression and dementia emerge as the most recurrent disorders, the first being more frequent (Oliveira, Gomes \& Oliveira, 2006). In addition, depression has an estimated prevalence of approximately 15\% in the population over 60 years old (Cunha, Bastos \& Duca, 2012), with a rate of variation between 5.4\% and 24.15\% (Pinho, Custódio \& Makdisse, 2009). It is a experience with large impact during this stage of life and the investigations have associated the depressions in the elderly with significant losses in the cognitive sphere (Lopes, Nascimento, Esteves, Terroso \& Argimon, 2013), which will lead to higher economic expenses (Oliveira, Gomes \& Oliveira, 2006), and in the latter case it may guide to suicide (de Paula Couto, Eschiletti Prati, Vieira da Silva Falcão \& Koller, 2008).

Several authors have suggested that depression in enderly is connected with relational losses and changes in community, family and occupational roles that happen throughout the aging process (Spar, La Rue, Falcato \& Jethá, 1999; Aranda \& Knight, 1997). Depression is also associated with low economic resources (Nunes, 2008), the deterioration of physical health (Nunes, 2008; West, Reed \& Gildengorin, 1998), weak social networks, and also to the loneliness (Oni, 2010; Singh \& Misra, 2009).

In Portugal, for the Direcção Geral da Saúde (2013), the elderly depression occurs at a time of life in which the main difficulties that relate to chronic diseases occur; somatic diseases; hypothyroidism; cancer; cardiovascular diseases; diabetes; rheumatic diseases; osteoarticular diseases; cognitive deficits; which may lead to loss of autonomy and self-esteem. Also the retirement may change the person's social status and contribute to social isolation, similarly with the possible occurrence of the death of the spouse that will influence the level of stress and the misfit of the reorganization of the person's life. The occurrence of all these facts, it may take the elder to be unable to overcome these events, and become more unprotected and subject to depression. However, the depression to be diagnosed may be associated with indecision, to the obstacles that are posed in the resolution of problems inherent in everyday life, such as loss of pleasure, guilt, changes in sleep and appetite (Direcção Geral da Saúde, 2013). It should be noted also, that psychiatric disorders of the elderly interfere negatively in the lives of those who are involved in their daily lives.

\subsection{Violence}

Associated with aging may also find it is the phenomenon of violence. According to the World Report on the Prevention of Violence (Butchart \& Mikton, 2014), violence is understood as the "intentional use of physical force or power, whether real or threatened, against an individual or against a group or community, which results in or is likely to result in injury, death, psychological damage, impairment to development or deprivation " (p. 84).

Violence against the elderly is more recent than other types of violence, as for example, the violence directed at women or children, and has been recognized as a medical and social problem since the three decades ago. Over the last few years it has been an under diagnosed and underreported problem. The recognition that the elderly were victims of maltreatment in the family and in the institutional context was later. Only in the late '70s, early' $80 \mathrm{~s}$, it is that this was recognized as a serious social problem. Professionals linked to formal health and social services entities were adapting to this problem, through the intervention to be developed particularly within the medical and social institutions (Dias, 2005; Vinton, 2001).

The recognition of violence against older women is a more recent phenomenon, which reveals how the differences are involved in all areas, since health to the social and political sector. Although the visibility of this problem is growing, the literature on domestic violence prior to 1990 is practically non-existent with regard to violence against older women, conjugal mistreatment and institutional abuse. The most recent investigations have been influenced by feminist models, as it has shown that violence is a fact that harms women at all ages. This has reinforced the feminist premise that violence against women can no longer be treated as an individualized issue. On the opposite, it is a question of gender and a serious public problem (Vinton, 2001).

Although there are not many studies on the prevalence of violence on the elderly, some investigations have been carried out in other countries, such as Australia, Canada, England and Northern Ireland, which have had concluded that the proportion of elderly people suffering from maltreatment varies between $3 \%$ and $10 \%$. In Canada, 55\% of the reported cases were abandonment, $15 \%$ physical maltreatment and $12 \%$ economic exploitation (Consejo Económico Y Social, Nações Unidas, 2002).

While in the United States, the National Center on Elder Abuse has over the past few years shared data about the incidence and prevalence of violence on the elderly. In a study of elder abuse by family members, Laumann et al. (2008) found that they reported verbal abuse more frequently (9\%), followed by financial maltreatment (3.5\%) and, finally, physical abuse (less than 1\%). In 2012, data available from the state's Adult Protective Services (APS) agencies also showed a growing trend in disclosure of elder abuse (Quinn \& Benson, 2012). Lachs and 
Pillemer (2015) found that prevalence of elder abuse was approximately 10\%, including physical abuse, psychological or verbal abuse, sexual abuse, financial exploitation and neglect.

In Portugal, between 2013 and 2016, the APAV (2017) recorded a total of 4,475 cases of support for the elderly, where 3,612 were victims of crime and violence. These figures translate into a total of 8,578 criminal acts. About $27 \%$ of the elderly victims of crime and violence were between 65 and 69 years old, were married $(42.8 \%)$ and belonged to a nuclear family type with children (31.7\%).

Violence against the elderly consists of "any act or omission (when it is normally described as" neglect "), whether intentional or unintentional, that causes harm or suffering to persons over 60 years of age - the age range for" elderly "varies from country to country, but often coincides with the official retirement age. The abuses, in turn, can be physical, sexual, psychological (involving emotional and / or verbal aggression) or financial; may entail material maltreatment and result in unnecessary suffering, injury or pain, loss or violation of human rights, and a decrease in the quality of life of the elderly " (Butchart \& Mikton, 2014, p.78).

It is considered violence against the elderly a single or repeated act, or lack of appropriate action, occurring in any relationship where there is an expectation of trust which causes harm or distress to an older person. It includes physical, sexual, psychological, emotional, financial and material abuse; abandonment; neglect and actions that compromise dignity and respect. The abuse may lead to "serious physical injury and long-term psychological consequences, including depression and anxiety" (Butchart \& Mikton, 2014, p.78). The results of violence on the elderly are devastating, and may include fractures, depression, anxiety, post-traumatic stress disorder, dementia, malnutrition, suicidal behavior, and even death.

According Anselmo (2007), the main predictors of risk of violence against the elderly is being female, married, with fragile health, older age, living accompanied, with psychological problems, inadequate, dependent behavior and situation social isolation. Belsky (1993) noted that the origin of ill-treatment should be studied from historical factors, contemporary, cultural, situational, and assigned to the characteristics of the people involved, which in most cases are family or direct caregivers.

\section{Methodology}

The purpose of this study was to understand the correlation between the elderly with depressive symptomatology and the predictors of the risk of violence against them.

\subsection{Procedures for Collecting Data and Sample}

Under the project ESACA - Aging in Alentejo Safety - Ref: ALT20-03-0145-FEDER-000007, funded by Alentejo 2020, Portugal 2020 and EU, a study was carried out with non-institutionalized elderly people from the Alentejo region. The sample consisted of elderly people who attended the program "Active Seniors" program and the Senior University of Évora, as well as elderly people linked to several associations in the District of Évora, who volunteered to participate in this research. The data collection took place between April and July 2017, at the Laboratory of Gerontopsychomotricity of the Nursing School of the Évora University, or in another place previously scheduled (for example, headquarters of the parish council) by research workers prepared for this purpose and familiar with the research protocol. All the ethical procedures of human research were followed. All the authorizations required for the study, as well the informed consent to the elderly were requested and all conditions of anonymity and confidentiality of the answers obtained were also guaranteed. The project was approved by the Ethics Committee of the Health and Welfare Area of the University of Évora under number 16012 of 05/19/2016. The inclusion criteria were age above 65 years, absence of severe cognitive deficit and being independent in their daily lives (Folstein, Folstein, \& McHugh, 1975). The sample consisted of 237 elderly people aged 65 and 96 years old, of both gender.

\subsection{Data Collection Instruments}

The instrument used to collect data was constructed from the adaptation of the Elder Abuse and Neglect-Risk Assessment Tool (E-IOA), after obtaining the authorization of the respective authors (Cohen, Halevi-Levin, Gagin \& Friedman, 2006) and also received with contributions from the Vulnerability to Abuse Screening Scale (VASS) adapted to the Brazilian reality by Maia (2014), who also granted authorization for this adaptation. This resulted in the instrument called Scale of Evaluation of the Risk of Violence against Non-institutionalised Elderly People (ARVINI), consisting of 36 questions, to which the elderly person has the option of answering: "yes, no and no answer". Each of the "yes" and "no" options was assigned a score of 1 or 0 . The 36 items aim to identify the risk of violence from four dimensions: Social Support and Isolation Network (1 to 12); Family context (13 to 25); Cognitive and emotional difficulties (26-30) and Financial issues (31-36), which respond to four dimensions present in the World Health Organization (2002) (physical, psychological, sexual and financial 
violence), not integrating the neglect. The scale score is obtained by adding together the values assigned to each of the items. The higher the result, the bigger the risk of violence on the elderly. This tool was made that was available to all professionals; little extensive; which does not involve specific training for its operationalization/implementation; is easy to apply and through which it is possible to achieve almost immediate results. The preliminary results of this scale were considered adequate in terms of reliability. The calculation of Cronbach's Alpha Coefficient was 0.916, which shows very good internal consistency (Mendes et al., 2018).

Another instrument used in this study was the Geriatric Depression Scale 15 (GDS - 15), validated and adapted for the Portuguese population by Pocinho, Farate, Dias, Lee \& Yesavage (2009). The questions from the Long Form GDS which had the highest correlation with depressive symptoms in validation studies were elected for the short version. It was developed in order to measure depressive symptoms in the elderly, and has the most highly correlated items with the diagnosis of depression. The scale consists of 15 questions, in which the elderly person has the option to answer "yes or no", according to "how you have been feeling in the last week." One point is awarded for the affirmative answer and zero for the negative answer. In items 1,5, 7, 11 and 13 have opposite score, that is, 1 point for the negative response and 0 for the affirmative answer. The final score is made through the sum of the 15 items. Regarding the cut-off point, for the Portuguese population, between 0 and 5 points does not present depression and values above 5 points present depression, namely 6-10 mild depression and 11-15 severe depression. Regarding the psychometric characteristics, the GDS-15 presents good internal consistency, with a Cronbach's alpha of 0.83 .

\subsection{Statistical Analysis}

Data analysis was performed using the IBM SPSS Statistics program version 24, using descriptive and inferential statistics methods. With regard to the data analysis procedures, and with reference to the objectives of the present study, descriptive statistics analysis was carried out, namely measures of central tendency and dispersion, with the results being presented in the form of frequencies absolute (number) and relative (percentage). Subsequently, analyzes of inferential statistics were performed. For the analysis of the prevalence of depressive symptomatology according to gender and marital status, the One-Way Anova was used. This test compares the means of two or more independent groups in order to determine whether there is statistical evidence that the associated population means are significantly different. To study the relationship between the GDS-15 and the ARVINI scale, for the analysis of the relationship of the different levels of depression with predictors of risk of violence, was performed a analysis protocol of the Chi-Square Test, that is a procedure for testing if two categorical variables are related in some population. Significance level was set at $\rho<0.05$.

\section{Results}

\subsection{Depressive Symptomatology According to Gender}

According to the data obtained, it was found that of the 237 elderly participants in the study, 168 were female and 69 were male. There are 173 elderly people who do not manifest any depressive symptoms, that is, about $73 \%$ of our sample. It should be added that 50 elderly (21.1\%) presented mild depressive symptoms, and 14 (5.9\%) had severe depressive symptomatology. Regarding mild depressive symptomatology, 42 are female and 8 are male. In respect to severe depressive symptoms, 13 individuals are female and 1 male. Data analysis showed that there are significant differences in gender due to depressive symptomatology, $\mathrm{F}(2,234)=5.2, \rho=.006$.

\subsection{Depressive Symptomatology According to Civil Status}

It was also analyzed the relationship between marital status and the existence of depression, and it was verified that of the 50 participants who present symptoms of mild depression, this has a majority representation in married elderly people, approximately $66 \%, 28 \%$ are widowers, that $4 \%$ are single, and $2 \%$ are divorced. Regarding the severe depressive symptomatology, of the 14 elderly, the majority are widowers (64.3\%), $28.6 \%$ married and $7.1 \%$ single. Significant differences were also observed in the marital status due to the depressive symptomatology of the participants, F $(2,234)=3.93, \rho=.021$.

\subsection{The Relationship Between Severity of Depressive Symptomatology and Predictors of Risk of Violence}

Given that the GDS-15 allowed us to organize our sample into three distinct levels of depressive symptomatology: without depression, mild depression and severe depression, we analyzed the data in order to perceive the correlation of the different levels of depression with predictors of risk of violence. Regarding these relationship, significant results were found in three dimensions of the ARVINI scale.

\subsubsection{Current Supports and Relationships}

In the first dimension, regarding the current supports and relationships, it was verified that the results obtained 
are correlated with the level of depressive symptomatology. Significant associations were found in four issues.

Table 1. Results of chi-square test and descriptive statistics for current supports and relationships dimension by the level of depressive symptomatology

\begin{tabular}{|c|c|c|c|c|c|}
\hline \multirow[b]{2}{*}{ Questions } & \multicolumn{3}{|c|}{ Level of depressive symptomatology } & \multirow[b]{2}{*}{$\chi^{2}$} & \multirow[b]{2}{*}{$\rho^{*}$} \\
\hline & $\begin{array}{l}\text { Without depression } \\
\qquad(\mathrm{n}=173)\end{array}$ & $\begin{array}{l}\text { Mild depression } \\
\quad(\mathrm{n}=50)\end{array}$ & $\begin{array}{l}\text { Severe depression } \\
\quad(\mathrm{n}=14)\end{array}$ & & \\
\hline \multicolumn{6}{|l|}{ "Feels alone oftentimes?" } \\
\hline Yes & $40(23.1 \%)$ & $32(64.0 \%)$ & $11(78.6 \%)$ & \multirow[t]{2}{*}{40.89} & \multirow[t]{2}{*}{0.000} \\
\hline No & $133(76.9 \%)$ & $18(36.0 \%)$ & $3(21.4 \%)$ & & \\
\hline \multicolumn{6}{|l|}{ "Is there someone that makes } \\
\hline & & & & \multirow[t]{3}{*}{18.92} & \multirow[t]{3}{*}{0.000} \\
\hline Yes & $145(83.8 \%)$ & $37(74.0 \%)$ & $5(35.7 \%)$ & & \\
\hline No & $28(16.2 \%)$ & $13(26.0 \%)$ & $9(64.3 \%)$ & & \\
\hline \multicolumn{4}{|l|}{$\begin{array}{l}\text { "There is someone to take you } \\
\text { shopping when you need it?" }\end{array}$} & \multirow{3}{*}{9.86} & \multirow{3}{*}{0.007} \\
\hline Yes & $151(87.3 \%)$ & $44(88.0 \%)$ & $6(42,9 \%)$ & & \\
\hline No & $22(12.7 \%)$ & $6(12.0 \%)$ & $8(57,1 \%)$ & & \\
\hline \multicolumn{4}{|l|}{$\begin{array}{l}\text { "Meets with the family every } \\
\text { week?" }\end{array}$} & \multirow{3}{*}{14.63} & \multirow{3}{*}{0.001} \\
\hline Yes & $153(88.4 \%)$ & $36(72.0 \%)$ & $8(57.1 \%)$ & & \\
\hline No & $20(11.6 \%)$ & $14(28.0 \%)$ & $6(42.9 \%)$ & & \\
\hline
\end{tabular}

$* \mathrm{p}<.05$

\subsubsection{Family Dimension}

In the second dimension, the family dimension, there were also significant associations in a few topics.

Table 2. Results of chi-square test and descriptive statistics for family dimension by the level of depressive symptomatology

\section{Level of depressive symptomatology}

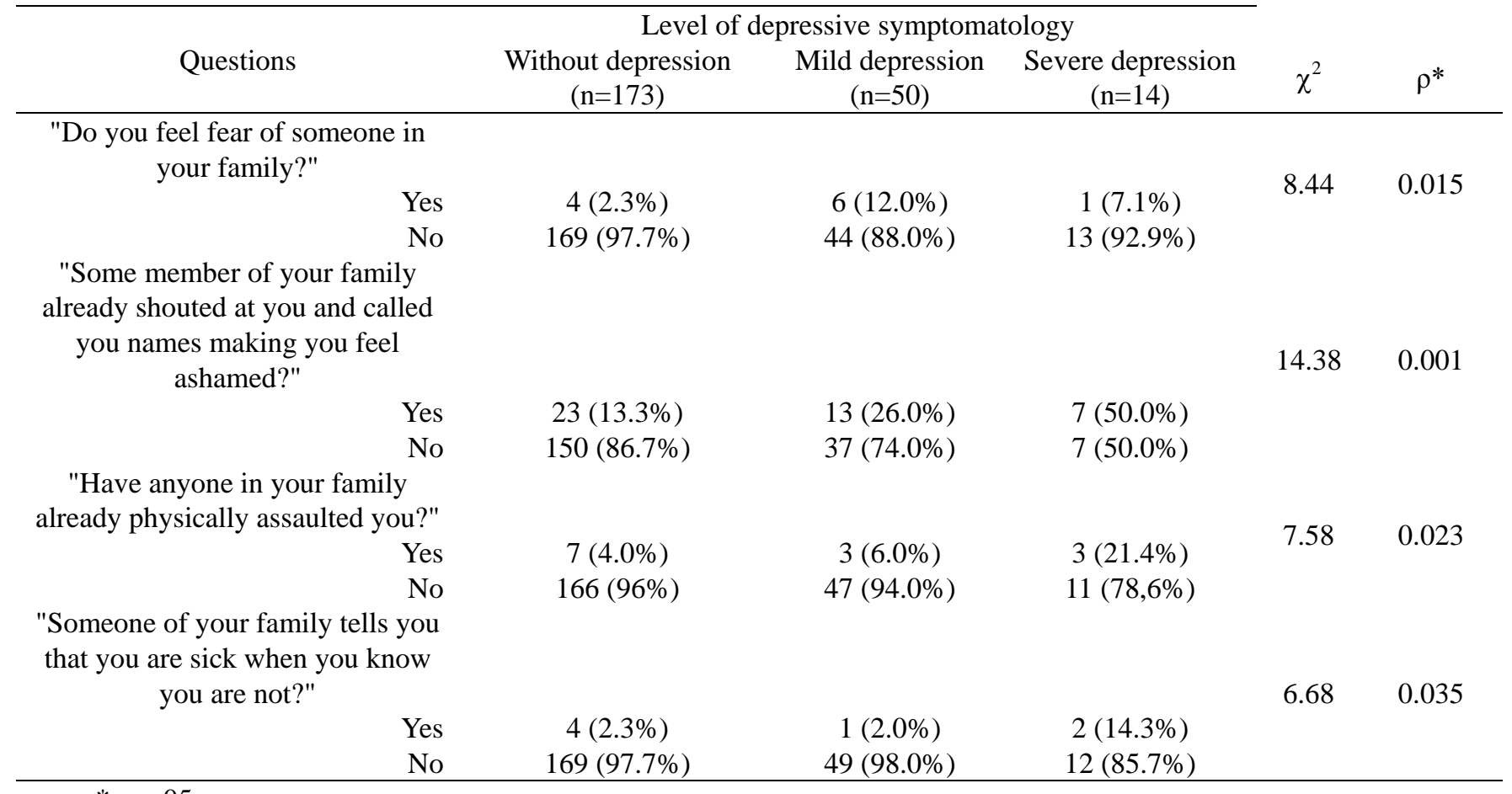




\subsubsection{Cognitive and Emotional Difficulties}

Finally, in the last dimension, two questions presented significant associations.

Table 3. Results of Chi-square Test and Descriptive Statistics for cognitive/emotional difficulties dimension by the level of depressive symptomatology

\begin{tabular}{|c|c|c|c|c|c|}
\hline \multirow[b]{2}{*}{ Questions } & \multicolumn{3}{|c|}{ Level of depressive symptomatology } & \multirow[b]{2}{*}{$\chi^{2}$} & \multirow[b]{2}{*}{$\rho^{*}$} \\
\hline & $\begin{array}{l}\text { Without depression } \\
\qquad(\mathrm{n}=173)\end{array}$ & $\begin{array}{l}\text { Mild depression } \\
\quad(\mathrm{n}=50)\end{array}$ & $\begin{array}{c}\text { Severe depression } \\
\quad(\mathrm{n}=14)\end{array}$ & & \\
\hline \multicolumn{4}{|l|}{$\begin{array}{c}\text { "You often feel } \\
\text { anxious / impatient?" }\end{array}$} & \multirow{3}{*}{38.94} & \multirow{3}{*}{0.000} \\
\hline Yes & $45(26.0 \%)$ & $35(70.0 \%)$ & $10(71.4 \%)$ & & \\
\hline No & $128(74.0 \%)$ & $15(30.0 \%)$ & $4(28.6 \%)$ & & \\
\hline \multicolumn{4}{|l|}{$\begin{array}{l}\text { "You often gets } \\
\text { irritated?" }\end{array}$} & \multirow{3}{*}{32.46} & \multirow{3}{*}{0.000} \\
\hline Yes & $37(21.4 \%)$ & $26(52.0 \%)$ & $11(78.6 \%)$ & & \\
\hline No & $136(78.6 \%)$ & $24(48.0 \%)$ & $3(21.4 \%)$ & & \\
\hline
\end{tabular}

\section{Discussion}

About the prevalence of depressive symptomatology in relation to gender, Blazer cited in Fontaine (2000, p.160), "1\% of the elderly with 60 years or older is severely depressed, and women have twice the depressive symptomatology comparatively (between $6 \%$ and $10 \%$ for men and $12 \%$ and $20 \%$ for women)". The study by Ekinci et al. (2004), found that women had higher levels of depression compared to men, but the authors justified the fact that women were the most representative number of the sample, as found in our study.

Regarding the relationship between the prevalence of depressive symptomatology and marital status, contrary to most of the studies already carried out (Direcção Geral da Saúde (2013); Gonçalves, 2011), our study revealed that the most depressed elderly are married. These results are in agreement with the data presented by Ekinci et al. (2004), where $61.1 \%$ of the married elderly also presented depression. However, it is important to reinforce that our results also are in accord with the literature, in cases of more severe symptomatology, which is present mostly in widowed elderly, as referred by Gonçalves (2011).

In the context of the first dimension of Predictors of Violence - current supports and relationships, in the question "feels alone oftentimes", most study participants answered affirmatively and it is the individuals with the depressive symptomatology to report that they feel alone more often. It is now understood that depression affects the elderly's image of themselves and of all that they involve, since this age group brings changes in their energy levels as well as their interpersonal and social relationships (Calha, Arriaga, Cordeiro, 2014; Oni, 2010).

In the second question "Is there someone that makes you company on a daily basis", were those with severe depression who said they did not keep them company on a daily basis. These results allow us to conclude that the capacity for socialization is essential for the elderly to gain and maintain their networks of support and relationships, and also contributes to the increase of their psychological and social well-being. It is evident that the social support received by the family, friends, neighbors and the surrounding community brings benefits at the affective, emotional, informative, instrumental, social, and also in the perception of oneself (Araújo \& Melo, 2011). Still, according to Andrade \& Vaistsman cited in (Domingues, 2011, p. 178) "friends usually, more commonly, perform instrumental activities, such as shopping, assisting in domestic activities or keeping company."

In the same sense, this network can fill support in everyday tasks. It is verified that it was the individuals with severe depressive symptomatology who stated that they do not have someone to accompany them in this type of daily tasks (having someone take him or her to the shop when he needs it). According to Domingues (2011), it is the neighbors who, as a matter of proximity, that can collaborate more easily in aiding the provision of services and supports.

In another issue, "meets with the family every week," it was individuals with severe depression who reported most not being able to be with their family every week. In the context of the study it is important to realize that in the Alentejo region the geographic distance between the direct relatives is common. Many people live in 
isolated rural environments, with a weak public transport network and mobility capacity to travel, which contributes to exacerbate social isolation. In fact, social relations are pillars that make us feel "secure, supported and understood, contributing to the definition of our identity, because what they think of us contributes to the image we are constructing of ourselves" (Araújo \& Melo , 2011, p.141).

The second dimension of Predictors of Violence is the family dimension. Ekinci, Tortumluoglu, Okanli, \& Sergin (2004), claim that overall, about $54.9 \%$ of depressed elderly people are dissatisfied with the family environment. Family violence can be considered as any kind of abuse relationship practiced in the private context of the family against any of its members, manifested as physical, psychological, sexual, financial, abandonment or neglect. It is understood as a "silent" violence, which is often suffered in silence, being practiced by children, grandchildren, spouses, siblings, acquaintances or neighbors who are close to the victim.

About the "do you feel fear of someone in your family" question, it is individuals with mild depression who report having more fear of their family members. In the questions, " some member of your family already shouted at you and called you names making you feel ashamed", "have anyone in your family already physically assaulted you", and " someone of your family tells you that you are sick when you know you are not", it is in people diagnosed with severe depression that they find a greater number of reports regarding these types of violence. According to data from the National Center on Elder Abuse (2008), violence against the elderly is seen as a worldwide problem that affects all populations regardless of socio-economic and cultural factors, and stresses that one of the risk factors is relationships family members, the distribution of inheritances, and the migration of some family components (Collins, 2006; Laks, Werner \& Miranda-Sá Júnior, 2006).

Concerning the third dimension, about cognitive / emotional difficulties, in the question "do you often feel anxious / impatient?", the individuals were individuals with severe depression who said they felt anxious and impatient with more frequency. Both anxiety and impatience are typical of depressive symptomatology. However, anxiety is to some extent also seen as a natural reaction, relevant for protection and adaptation to new situations, but becomes pathological, when it reaches an extreme and generalized character, accompanied by symptoms of tension, fear, in which the focus of the hazard may be external or internal. In the same way that may be relevant for protection and adaptation to new situations, anxiety may also have a negative impact on the quality of life of the elderly (Cheik et al., 2008).

The process of senescence is considered dynamic, gradual and full of physical and psychosocial modifications. These changes eventually contribute to the vulnerability of the elderly, making them more susceptible to certain health problems, as well as to the emergence of diseases (Wamser et al, 2015). The inherent losses of aging lead to feelings of anxiety, fear, sadness, irritation and the urgency of adapting to a new lifestyle (dos Santos, Ribeiro, de Oliveira Barbosa Rosa, \& de Cassia Lanes Ribeiro, 2015). The prevalence of pathologies associated with the elderly also increases the symptoms of anxiety and depression (Tavares, Scalco, Vieira, da Silva \& Bastos, 2013). Some of these pathologies are sources of emotional distress and consequently circumscribe the quality of life of the elderly (Gomes \& Reis, 2016). In old age, anxiety can also be related to the lack of physical support, social and setbacks in interpersonal relationships, leading to psychological distress (Gomes \& Reis, 2016).

In the question "you often gets irritated", the highest levels of irritability are manifested by people with severe depressive symptoms. According to Ramos (2003), throughout the aging process the human being can develop a feeling of finitude of life, ending up evaluating in a negative way, triggering a depressive state, which is characterized by sensations of uselessness, insufficiency, anxiety and irritability, which can lead to lack of motivation, family withdrawal, progressive physical limitation, feelings of impotence, lack of autonomy, and increased emotional and financial dependence. This statement is in line with our results, they really are individuals with higher levels of depressive symptoms who report higher levels of anxiety and irritability.

\section{Conclusion}

The depressive symptomatology is mostly present in the female elderly. If mild depression affects mainly the married elderly, a fact contradictory to most studies, severe depressive symptomatology appears mainly in the elderly widowers, a situation that is in agreement with most of the studies consulted.

In the relationship between the severity of depressive symptomatology and the predictors of violence risk, it is emphasized that the absence of a network supports and current relationships, the family context and cognitive / emotional difficulties emerge as central dimensions of this relationship. These data reinforce the importance of the aging process taking place in a family and socially inclusive environment, with the approximation of neighbors, friends and family members who promote easy access to goods and services necessary for their daily life, ie with a support network and relationships. The fight against isolation and the promotion of family and social inclusion, together with the active promotion of mental health, contributing to prevent and avoid 
depression and mitigate the risk of violence.

In fact, the lack of a formal and informal social support network generates greater physical and mental vulnerability, which is conducive to the occurrence of both depression and an increased risk of violence. Likewise, intrafamily divergences can result in anxiety and stress (Fernandes \& Botelho, 2007), leading to situations of violence on the elderly, either by family members or other caregivers, which cannot continue to be vulgarized. This is a social problem that must be analyzed, understood and for which urgent scientific and political intervention is needed. As the number of older people increases, this is likely to become a growing problem (Consejo Económico Y Social, Nações Unidas, 2002).

In this way, social support at this stage of life can have a promoting function of quality of life, thus contributing to active aging, which is understood as the process of optimizing health, participation and safety opportunities, with the objective of improving the quality of life, quality of life as people gets older. According to Cabral \& Silva (2010), although it is desirable to obtain healthy lifestyles and good health habits, sociologically these convictions can bring about inequality between people in relation to health and illness, since these facts are related to the social determinants, which in turn are not under the control of all the elderly.

Mental health has also been approached as a risk factor, considering the evaluation of cognitive capacity and depressive symptomatology. Our results are consistent with some studies that have evaluated the existence of mental pathology and observed a higher percentage of victims of violence with mental health problems (Grande et al., 2000). To date, depressive symptoms as a risk factor have been analyzed in other studies. In the United Kingdom (O'Keefe et al., 2007), depressive symptomatology was understood as a precipitant factor of violence in general, while in Canada (Podnieks, 1993) this variable increased vulnerability to financial, physical and psychological violence. In Portugal, our study allowed us to conclude that depressive symptomatology presents a significant correlation with the predictors of violence risk in this age group. Depressive symptomatology, although it seems to be relevant and must be explored, is difficult to assess as a risk factor, since it is not possible to conclude whether depressive symptoms constitute the cause or are the consequence of the victimization process itself.

Knowledge of this relationship (depression and risk of violence) allows professionals to have scientific evidence to support and justify their interventions both in preventing depression and in preventing the risk of violence on the elderly. Detecting violence is a necessity and a responsibility of the health professional. Professionals should be alert that they will face some obstacles and barriers that may hold back or interfere. It is necessary to recognize and overcome the difficulties. They can come from older people themselves, families, caregivers, the professionals themselves and even the society that does not see violence against the elderly.

The importance of further studies that contribute to establishing the relationship between depression and risk of violence is crucial in increasing the levels of scientific evidence and at the same time promoting more effective interventions in daily health and social work with the elderly.

\section{Acknowledgements}

Co-financed by the European Union through the European Regional Development Fund, under the ALENTEJO 2020 (Regional Operational Program of the Alentejo) through the project ESACA- Aging in Alentejo Safety Ref: ALT20-03-0145-FEDER-000007 with the reference ALT20-03-0145-FEDER-000007. The authors thank all the participants and institutions for their contribution in this work, namely the University of Évora, the National Confederation of Solidarity Institutions (CNIS) and Regional Health Administration of Alentejo, I.P., (ARS Alentejo).

\section{References}

Anselmo, M. (2007). Caderno de violência contra a pessoa idosa. Violência doméstica contra a pessoa idosa: orientações gerais.

APAV. (2017). Estatísticas APAV-Pessoas idosas vítimas de crime e de violência 2013-2016. Retrieved February 2, 2018, from https://apav.pt/apav_v3/images/pdf/Estatisticas_APAV_Pessoas_Idosas_2013_2016.PDF

Aranda, M.P., \& Knight, B.G. (1997). The influence of ethnicity and culture on the caregiver stress and coping process: A sociocultural review and analysis. The Gerontologist, 37(3), 342-354. https://doi.org/10.1093/geront/37.3.342

Araujo, L., \& Melo, S. (2011). Capítulo 6-Relacione-se com os outros. In Ribeiro O. \&Paúl C. (Eds.), Manual de Envelhecimento Ativo. Lisboa: Lidel.

Belsky, J. (1993). Etiology of child maltreatment: A developmental ecological analysis. Psychological Bulletin, 
114, 413. https://doi.org/10.1037/0033-2909.114.3.413

Bronfenbrenner, U. (1996). A ecologia do desenvolvimento humano. Porto Alegre: Artes Médicas.

Bronfenbrenner, U. (2005). Making human beings human: Bioecological perspectives on human development. Sage.

Butchart, A., \& Mikton, C. (2014). Global status report on violence prevention.

Calha, A., Arriaga, M., \& Cordeiro, R. (2014). Prevalência da solidão e depressão na população idosa residente na zona histórica da cidade de Portalegre. Revista Portuguesa de Enfermagem de Saúde Mental, (SPE1), 9-14.

Cheik, N.C., Reis, I.T., Heredia, R.A., de Lourdes Ventura, M., Tufik, S., Antunes, H.K., \& de Mello, M.T. (2008). Efeitos do exercício físico e da atividade física na depressão e ansiedade em indivíduos idosos. Revista Brasileira de Ciência e Movimento, 11(3), 45-52.

Cohen, M. (2013). The process of validation of a three-dimensional model for the identification of abuse in older $\begin{array}{lllll}\text { adults. Archives of Gerontology and } & \text { Geriatrics, 57(3), 249. }\end{array}$ https://doi.org/10.1016/j.archger.2013.06.009

Cohen, M., Halevi-Levin, S., Gagin, R., \& Friedman, G. (2006). Development of a screening tool for identifying elderly people at risk of abuse by their caregivers. Journal of Aging and Health, 18(5), 660-685. https://doi.org/10.1177/0898264306293257

Collins, K.A. (2006). Elder maltreatment: a review. Archives of Pathology \& Laboratory Medicine, 130(9), 1290-1296.

Consejo Económico Y Social, Nações Unidas. (2002). El maltrato de las personas de edad: reconocer y responder al maltrato de las personas de edadenun contexto mundial. Retrieved February 24, 2018, from http://www.hartuemanak.org/informacion/biblioteca/

Cunha, R.V.D., Bastos, G.A.N., \& Duca, G.F.D. (2012). Prevalence of depression and associated factors in a low income community of Porto Alegre, Rio Grande do Sul. Revista Brasileira de Epidemiologia, 15(2), 346-354. https://doi.org/10.1590/S1415-790X2012000200012

de Paula Couto, M.C.P., Eschiletti Prati, L., Vieira da Silva Falcão, D., \& Koller, S.H. (2008). Terapia familiar sistêmica e idosos: contribuições e desafios. Psicologia clínica, 20(1).

Dias, I. (2005). Envelhecimento e violência contra os idosos. Sociologia: Revista da Faculdade de Letras da Universidade do Porto, 25, 249-273.

Dias, I., \& Ferreira, M. (2014) Envelhecimento e saúde: de realidade biológica a objecto da sociologia. In Leandro \& Monteiro (Eds.), Saúde no Prisma da Sociologia-Olhares Plurais. Viseu: Psicosoma

Direcção Geral da Saúde. (2013). Portugal Saúde Mental em Números-2013. Programa Nacional para a Saúde Mental. Retrieved June 20, 2015, from https://www.dgs.pt/estatisticas-de-saude/estatisticas-de-saude/publicacoes/portugal-saude-mental-em-numer os-2013.aspx

Domingues, M. (2011). Capítulo 12-Mapa minino de relações do Idoso. Uma ferramenta para avaliar o suporte social. In Pereira F. (Ed.), Teoria e Prática da Gerontologia-Um Guia para Cuidadores de Idosos. Viseu: Psicosoma.

dos Santos, C.A., Ribeiro, A.Q., de Oliveira Barbosa Rosa, C., \& de Cassia Lanes Ribeiro, R. (2015). Depressão, déficit cognitivo e fatores associados à desnutrição em idosos com câncer. Revista Ciência \& Saúde Coletiva, 20(3). https://doi.org/10.1590/1413-81232015203.06252014

Ekinci, M., Tortumluoğlu, G., Okanll, A., \& Sezgin, S. (2004). The prevalence of depression in elderly living at home in Eastern Turkey: Erzurum. Journal of Human Sciences, 1(1).

Fernandes, A.A., \& Botelho, M.A. (2007, January). Envelhecer activo, envelhecer saudável: o grande desafio. In Forum Sociológico, Série II (No. 17, pp. 11-16). CESNOVA.

Folstein, M.F., Folstein, S.E., \& McHugh, P.R. (1975). "Mini-mental state": a practical method for grading the cognitive state of patients for the clinician. Journal of Psychiatric Research, 12(3), 189-198. https://doi.org/10.1016/0022-3956(75)90026-6

Fontaine, R., \& de Almeida, J.N. (2000). Psicologia do envelhecimento. 
Gomes, J.B., \& dos Reis, L.A. (2016). Descrição dos sintomas de Ansiedade e Depressão em idosos institucionalizados no interior da Bahia, Brasil. Revista Kairós: Gerontologia, 19(1), 175-191.

Gonçalves, A.R.B.M. (2011). Declínio cognitivo, sintomas ansiosos e depressivos: Estudo em idosos sob resposta social no concelho de Coimbra (Bachelor's thesis, ISMT).

Grande, E.D., Woollacott, T., Taylor, A., Starr, G., Anastassiadis, K., Ben-Tovim, D., ... Goulding, S. (2000). Interpersonal violence and abuse survey. Adelaide: South Australian Department of Human Services.

Koller, S.H., \& De Antoni, C. (2004). Violência intrafamiliar: Uma visão ecológica. Ecologia do desenvolvimento humano: Pesquisa e intervenção no Brasil, 293-310.

Lachs, M.S., \& Pillemer, K.A. (2015). Elder abuse. New England Journal of Medicine, 373(20), 1947-1956. https://doi.org/10.1056/NEJMra1404688

Laks, J., Werner, J., \& Miranda-Sá Júnior, L.S. (2006). Psiquiatria forense e direitos humanos nos pólos da vida: $\begin{array}{llllll}\text { crianças, adolescentes e idosos. Rev Bras Psiquiatr, } 28(2), & 80-85 .\end{array}$ https://doi.org/10.1590/S1516-44462006000600006

Laumann, E.O., Leitsch, S.A., \& Waite, L.J. (2008). Elder mistreatment in the United States: Prevalence estimates from a nationally representative study. The Journals of Gerontology Series B: Psychological Sciences and Social Sciences, 63(4), S248-S254. https://doi.org/10.1093/geronb/63.4.S248

Lopes, R.M.F., do Nascimento, R.F.L., Esteves, C.S., Terroso, L.B., \& de Lima Argimon, I.I. (2013). Funções executivas de idosos com depressão: um estudo comparativo. Cuadernos de neuropsicología, 7(2), 72-86.

Maia, R.S. (2014). Adaptação Transcultural para o Português/Brasil do Instrumento Vulnerability to Abuse Screening Scale (VASS). Rio Grande do Norte (Doctoral dissertation, Dissertação [Mestrado em Psicologia]-Universidade Federal do Rio Grande do Norte).

Mendes, F., Zangão, O., Gemito, L., Chora, M.A., Mestre, T., \& Pereira, J.A. (2018). Risk of Violence against the Elderly-ARVINI Scale Test. Manuscript submitted for publication.

Narvaz, M.G., \& Koller, S.H. (2004). O modelo bioecológico do desenvolvimento humano. Ecologia do desenvolvimento humano: pesquisa e intervenção no Brasil, 51-65.

National Center on Elder Abuse. (n.d.). Types of Elder Abuse in Domestic Settings. American Public Human Services Association. Retrieved June 12, 2008, from www.ncea.aoa.gov

Nunes, B. (2008). Envelhecer com Saúde: Guia para melhorar a sua saúde física e psíquica. Lousã. Lidel.

O'Keeffe, M., Hills, A., Doyle, M., McCreadie, C., Scholes, S., Constantine, R., ... Erens, B. (2007). UK study of abuse and neglect of older people: Prevalence survey report.

Oliveira, D.A., Gomes, L., \& Oliveira, R.F. (2006). Prevalência de depressão em idosos que freqüentam centros de convivência. Revista de Saúde Pública, 40, 734-736. https://doi.org/10.1590/S0034-89102006000500026

Oni, O.O. (2010). Social support, loneliness and depression in the elderly (Doctoral dissertation).

Pinho, M.X., Custódio, O., \& Makdisse, M. (2009). Incidência de depressão e fatores associados em idosos residentes na comunidade: revisão de literatura. Revista Brasileira de Geriatria e Gerontologia, 12(1), 123-140. https://doi.org/10.1590/1809-9823.2009120111

Pocinho, M.T., Farate, C., Dias, C.A., Lee, T.T., \& Yesavage, J.A. (2009). Clinical and psychometric validation of the geriatric depression scale (GDS) for portuguese elders. Clinical Gerontologist, 32(2), 223-236. https://doi.org/10.1080/07317110802678680

Podnieks, E. (1993). National survey on abuse of the elderly in Canada. Journal of Elder Abuse \& Neglect, 4(1-2), 5-58. https://doi.org/10.1300/J084v04n01_02

Poletto, M., \& Koller, S.H. (2008). Contextos ecológicos: promotores de resiliência, fatores de risco e de proteção. Estudos de psicologia, 25(3), 405-416. https://doi.org/10.1590/S0103-166X2008000300009

Pordata. (n.d.). Base de Dados Portugal Contemporâneo. Retrieved July, 2, 2018, from https://www.pordata.pt/Portugal/Indicadores+de+envelhecimento-526

Queiroz, M., Vicente, V., Alves, C., Silva C., \& Negreirom F. (2009). Saúde em Mapas e Números-Eurotrials: Consultores Científicos. $\quad$ Retrieved May, 8, 2015, from http://www.eurotrials.com/wpcontent/uploads/2014/02/publicacao_ficheiro_115_1.pdf 
Quinn, K., \& Benson, W. (2012). The states' elder abuse victim services: A system in search of support. Generations, 36(3), 66-72.

Ramos, L.R. (2003). Fatores determinantes do envelhecimento saudável em idosos residentes em centro urbano: Projeto Epidoso, São Paulo. Cadernos de Saúde Pública, 19, 793-797. https://doi.org/10.1590/S0102-311X2003000300011

Sheikh, J.I., \& Yesavage, J.A. (1986). Geriatric Depression Scale (GDS): recent evidence and development of a shorter version. Clinical Gerontologist: The Journal of Aging and Mental Health.

Singh, A., \& Misra, N. (2009). Loneliness, depression and sociability in old age. Industrial Psychiatry Journal, 18(1), 51. https://doi.org/10.4103/0972-6748.57861

Spar, J.E., La Rue, A., Falcato, J.A., \& Jethá, C. (1999). Guia de psiquiatria geriátrica.

Tavares, K.O., Scalco, J.C., Vieira, L., da Silva, J.R., \& Bastos, C.C.C.B. (2013). Envelhecer, adoecer e tornar-se dependente: a visão do idoso. Revista Kairós: Gerontologia, 15(2), 105-118.

Vinton, L. (2001). Violence against older woman. In Claire M. Renzetti, Jeffrey L. Edleson, \& Raquel Kennedy Bergen (Eds.), Sourcebook on Violence Against Women (pp. 179-191). California, Sage.

Wamser, E.L., Valderramas, S.R., Schieferdecker, M.E.M., Amarante, T.P., Coelho, R.A., Guimarães, A.T.B., \& Gomes, A.R.S. (2015). Melhor desempenho no teste timed up and go está associado a melhor desempenho funcional em idosas da comunidade. Geriatrics, Gerontology and Aging, 9(4), 138-143. https://doi.org/10.5327/Z2447-2115201500040003

West, C.G., Reed, D.M., \& Gildengorin, G.L. (1998). Can money buy happiness? Depressive symptoms in an affluent older population. Journal of the American Geriatrics Society, 46(1), 49-57. https://doi.org/10.1111/j.1532-5415.1998.tb01012.x

World Health Organization (WHO). (2002). The Toronto Declaration on the Global Prevention of Elder Abuse. WHO Press.,Geneva, Switzerland. Retrieved July 12, 2017, from http://www.who.int/ageing/publications/toronto_declaration/en/

World Health Organization. (2008). The world health report 2008: primary health care now more than ever: introduction and overview.

Yesavage, J.A., Brink, T.L., Rose, T.L., Lum, O., Huang, V., Adey, M., \& Leirer, V.O. (1982). Development and validation of a geriatric depression screening scale: a preliminary report. Journal of Psychiatric Research, 17(1), 37-49. https://doi.org/10.1016/0022-3956(82)90033-4

Zimerman, G.I. (2009). Velhice: aspectos biopsicossociais. Artmed Editora.

\section{Copyrights}

Copyright for this article is retained by the author(s), with first publication rights granted to the journal.

This is an open-access article distributed under the terms and conditions of the Creative Commons Attribution license (http://creativecommons.org/licenses/by/4.0/). 